\title{
A BRIEF RADIOGRAPHIC REPORT FROM TWO COMMON ODONTOGENIC CYSTS IN JAWS WITH FOLLICULAR RADIOLUCENT APPEARANCE
}

\author{
Çenelerdeki Foliküler Radyolüsent Görünümlü İki Ortak Odontojenik Kistten Kısa Bir \\ Radyografik Rapor
}

\author{
Adineh Javadian Langaroodi ${ }^{1}$ Seyed Hossein Hoseini Zarch ${ }^{2}$ Amin Rahpeyma ${ }^{3}$ \\ Nasim Khaki ${ }^{4}$ Alireza Esmaeilzade ${ }^{5}$ Hamed Ebrahimnejad ${ }^{6}$
}

\section{Makale Kodu/Article Code $\quad$ : 163098 \\ Makale Gönderilme Tarihi \\ :27.12. 2015 \\ Kabul Tarihi}

ABSTRACT

Objectives: Pericoronal radiolucencies are common pathologic findings in regular dental checkups. Since dentigerous cyst is the most common pathologic pericoronal radiolucency and as odontogenic keratocyst $(\mathrm{OKC})$ is a common cyst also and an aggressive lesion with high recurrence, radiographic features of these lesions were discussed in this study using panoramic radiography and cone beam computed tomography.

Materials and Methods: In this cross-sectional case series study, radiographs from 56 patients who were referred to a private maxillofacial radiology center or dentistry faculty in Mashhad/Iran from 2008 to 2013 in which radiolucent pericoronal lesion was observed in jaws with histopathologic results of dentigerous cyst or OKC were separately examined by two maxillofacial radiologists. Both observers were unaware of pathology results. Lesions were assessed based on their location, periphery, and impaction on the surrounding structures. Then, obtained data were analyzed using descriptive tables. Results: 56 lesions were identified in 56 patients. There were 20 odontogenic keratocyst and 36 dentigerous cysts. The majority of dentigerous cysts and OKCs occurred in the posterior mandible and showed a well corticated border. External root resorption was higher in OKC cases. In addition, displacement tendency of surrounding structures (other than tooth) such as nasal floor, mandibular canal, buccal and lingual cortex (in the form of expansion) as well as destruction of cortex, nasal floor or sinus walls was higher in $\mathrm{OKC}$ than in dentigerous cyst.

Conclusion: Except of tooth displacement other parameters related to the effect on surrounding structures in this study showed higher frequency in $\mathrm{OKC}$ than dentigerous cyst.

Key words: odontogenic cyst, panoramic radiography, cone beam computed tomography, odontogenic keratocyst, dentigerous cyst

\section{ÖZ}

Amaç: Perikoronal radyolüsensiler rutin dişhekimliği muayenelerinde yaygın patolojik bulgulardır. Dentigeröz kist en yaygın patolojik perikoronal radyolüsensi ve aynı zamanda odontojenik keratokist (OKC) yaygın ve yüksek nüks gösteren agresif bir lezon olduğundan dolayı, bu lezyonların radyografik özellikleri panoramik radyografi ve konik ışınlı bilgisayarlı tomografi kullanılarak tartışıldı.

Gereç ve Yöntem: Bu kesitsel vaka serisi çalıșmasında 2008-2013 yılları arasında Mashhad / İran'da özel maksillofasiyal radyoloji merkezine veya dişhekimliği fakültesine sevk edilen 56 hastanın radyolüsent perikoronal lezyonunun dentigeröz kist veya OKC'nin histopatolojik sonuçları ile çenelerde görüldüğü radyografileri ik maksillofasiyal radyolog tarafindan ayrı ayrı incelendi. Her iki gözlemci de patoloji sonuçlarının farkında değildi. Lezyonlar, yerleri, cevresi ve çevreleyen yapılar üzerindeki etkisine göre değerlendirildi. Elde edilen veriler tanımlayıcı tablolar kullanılarak analiz edildi. Bulgular: 56 hastada 56 lezyon tespit edildi. $20 \mathrm{OKC}$ ve 36 dentigerö kist vardı. Dentigeröz kistlerin ve OKC'lerin çoğunluğu posterior mandibulada ortaya çıkmıș ve iyi kortekslenmiș bir sınır göstermiștir. OKC olgularında dış kök rezorpsiyonu daha yüksekti. Ek olarak, burun zemini, mandibuler kanal, bukal ve lingual korteks (genisleme şeklinde) gibi çevreleyen yapıların (diş hariç) yer değiştirme eğilimleri, korteks, burun zemini veya sinüs duvarlarının tahrip edilmesi, OKC'de dentigerous kistten daha yüksekti.

Sonuçlar: Bu çalışmada, diș yer değiștirmesinin haricinde, çevre yapılara etkisi ile ilgili diğer parametreler OKC'de dentigeröz kistten daha yüksek dağılım gösterdi.

Anahtar Kelimeler: odontojenik kist, panoramik radyografi, konik ışınlı bilgisayarlı tomografi, odontojenik keratokist, dentigeröz kist

\footnotetext{
${ }^{1}$ Oral and Maxillofacial Diseases Research Center, Department of Oral and Maxillofacial Radiology, School of Dentistry, Mashhad University of Medical Sciences, Mashhad, Iran

${ }^{2}$ Dental Materials Research Center. Department of Oral and Maxillofacial Radiology, School of Dentistry, Mashhad University of Medical Sciences, Mashhad, Iran

${ }^{3}$ Dental Research Center, Department of Oral and Maxillofacial Surgery, School of Dentistry, Mashhad University of Medical Sciences, Mashhad, Iran

${ }^{4}$ Post Graduate Student of Oral and Maxillofacial Radiology, School of Dentistry, Mashhad University of Medical Sciences, Mashhad, Iran

${ }^{5}$ Private Dental Practice, Noor, Iran

${ }^{6}$ Oral and Maxillofacial Radiologist, Kerman, Iran
} 


\section{INTRODUCTION}

Dental follicles associated with impacted teeth are remnants of tissues that participated in teeth formation and remain attached to the teeth. Despite the physiological role of dental follicle in growth, histopathologic changes in different stages of growth can lead to development of odontogenic cysts and tumors. ${ }^{1}$ Pericoronal radiolucencies are common pathologic findings in regular dental practice. These lesions are typically observed as a normal or slightly enlarged follicle in radiographies, which sometimes show larger lesions needing appropriate intervention and histopathological interpretation. ${ }^{2}$ Pericoronal space larger than $2.5 \mathrm{~mm}$ in intraoral radiography or larger than $3 \mathrm{~mm}$ in panoramic radiography should be considered as suspicious. ${ }^{3}$ Several pathological processes may be radiographically manifested as radiolucencies associated with impacted tooth. These lesions can grow significantly and have the potential of pathological displacement. ${ }^{4}$ Pericoronal radiolucencies are a diagnostic dilemma because of multiple differential diagnoses and different treatments. Therefore, differentiation of these lesions from each otheris essential to avoid unnecessary medical intervention. ${ }^{5}$ Cases commonly causing pericoronal radiolucencies include hyperplastic follicular space, dentigerous cyst, odontogenic keratocyst, mural (unicystic) ameloblastoma, adenomatoid odontogenic tumor, calcified odontogenic cyst and ameloblastic fibroma. ${ }^{6,7}$

Since dentigerous cyst is the most common pathologic pericoronal radiolucency and $\mathrm{OKC}$ is a common and aggressive lesion with high recurrence that can present with an appearance similar to dentigerous cyst, in this study radiographic features of these lesions were investigated using panoramic radiography and cone beam computed tomography (CBCT).

\section{MATERIALS AND METHODS}

In this cross-sectional case-series study, images from 56 patients that showed a pericoronal and unilocular radiolucent lesions in panoramic (Planmeca Model 2007 ProlineXC instrument made in Finland) or CBCT (using Planmeca Model 2009 ProMax3D device made in Finland with 320- and 160-micron resolution) images with histopathology results of dentigerous cyst or $\mathrm{OKC}$ in a private maxillofacial radiology center and Mashhad Dental School were calculated from 2008 to 2013 . The images have been prescribed as a diagnostic workup. This study was approved by the ethical committee of Mashhad University of Medical Sciences (Mashhad/Iran) regarding ethical and methodological issues.

Two qualified radiologists reviewed the images separately. Observers had no knowledge of the histopathological results. In case they did not concur, a third opinion was sought through consultation with another expert who was also blind to pathology reports.

The radiographic features of these lesions, including the involved site, border of lesion, and effect on surrounding structures were recorded in a checklist in this study.

\section{Location}

The lesions could be situated in the anterior (incisor-canine) and posterior (pre-molar/ molar/ ramus (mandible) / tuberosity (maxilla) of the mouth, or even extend from anterior to posterior.

\section{Border}

The periphery of the lesions included three categories; well-corticated, well-sclerotic and well non-corticated.

\section{Effect on surrounding structures}

A range of findings were also studied including root resorption, tooth displacement, cortical perforation, mandibular canal displacement due to mandibular lesions and maxillary sinus and 
nasal walls displacement owing to maxillary lesions.

Finally, frequency distribution tables and charts were used to describe the data. It should be noted that evaluation of findings such as destruction of buccal and lingual cortex, nasal or sinus walls is only possible through sectional images such as CBCT and CT, and in this study, these findings were assessed only in patients with CBCT images. Cases associated with effect on mandibular canal, nasal or sinus walls were calculated from among cases in the respective jaw in close proximity to these structures, and frequency of external root resorption and displacement of adjacent teeth were also checked and calculated from among the cases adjacent to teeth.

\section{RESULTS}

56 lesions in 56 patients were studied. 36 cases of dentigerous cyst and 20 cases of odontogenic keratocyst were observed.

Most patients with dentigerous cyst and OKC were in the second decade of their life ( $41.17 \%$ and $42.85 \%$, respectively). $52.94 \%$ of patients with dentigerous cyst were male and $47.06 \%$ were female, while OKC showed the same frequency in men and women. All 56 patients in the study had a panoramic radiography image.

In this study, CBCT was used as additional imaging technique in $40 \%$ of dentigerous cyst lesions in maxilla and $8 \%$ in mandible, which was $50 \%$ and $25 \%$ in relation to $\mathrm{OKC}$, respectively.

\section{Frequency distribution of lesions according to location}

The results of our study on dentigerous cyst location showed that a total of $72 \%$ of the lesions occurred in the mandible, and almost $85 \%$ of lesions tended to occur in the posterior mandible. In maxilla, the lesions had a relatively higher anterior tendency. OKC was found in mandible in $60 \%$ of cases. Mandibular lesions had a higher posterior tendency but the majority of lesions in maxilla had anteroposterior extension. (Table 1)

Table 1. Frequency distribution of lesions based on the involved site

\begin{tabular}{|c|c|c|c|c|c|}
\hline & Location & Anterior & Posterior & $\begin{array}{c}\text { anterior to } \\
\text { posterior }\end{array}$ & Total \\
\hline \multirow{3}{*}{ Dentigerous cyst } & Mandible & $1(3.8 \%)$ & $22(84.6 \%)$ & $3(11.5 \%)$ & $26(72.2 \%)$ \\
\cline { 2 - 6 } & Maxilla & $4(40.0 \%)$ & $3(30.0 \%)$ & $3(30.0 \%)$ & $10(27.7 \%)$ \\
\cline { 2 - 6 } & Total & $5(13.9 \%)$ & $25(69.4 \%)$ & $6(16.7 \%)$ & $36(100 \%)$ \\
\hline \multirow{2}{*}{ OKC } & Mandible & $3(25.0 \%)$ & $8(66.7 \%)$ & $1(8.3 \%)$ & $12(60.00 \%)$ \\
\cline { 2 - 6 } & Maxilla & $1(12.5 \%)$ & $1(12.5 \%)$ & $6(75.0 \%)$ & $8(40.0 \%)$ \\
\cline { 2 - 6 } & Total & $4(20.0 \%)$ & $9(45.0 \%)$ & $7(35.0 \%)$ & $20(100.0 \%)$ \\
\hline
\end{tabular}

\section{Frequency distribution of lesions according to border:}

The majority of dentigerous cysts both in mandible (73.1\%) and maxilla (50\%) had wellcorticated borders. Most cases of OKC had also well-corticated borders in the mandible (83.3\%) and maxilla $(87.5 \%)$. Only four dentigerous cysts had well-sclerotic margin, two in mandible and two in maxilla. (Table 2)

Table 2. Frequency distribution of lesions based on the border

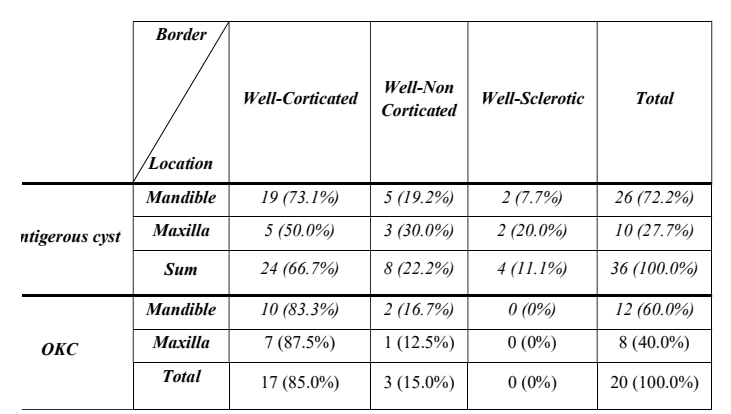

\section{Frequency distribution of lesions according to their effect on surrounding structures}

The results of our study showed that external root resorption was more frequent inOKC. Furthermore, displacement tendency of surrounding structures (other than teeth) such as nasal walls, mandibular canal or buccal and lingual cortex (in the form of expansion) as well as destruction of cortex, nasal or sinus walls was 
higher in $\mathrm{OKC}$ than dentigerous cyst. (Table 3 ) (Fig.1, 2 and 3)

Table 3. Frequency distribution of lesions based on the effect on surrounding structures

\begin{tabular}{|c|c|c|c|c|c|c|}
\cline { 2 - 7 } \multicolumn{1}{c|}{} & \multicolumn{3}{c|}{ Dentigerous cyst } & \multicolumn{3}{c|}{ OKC } \\
\hline $\begin{array}{c}\text { The effect on } \\
\text { surrounding } \\
\text { structures }\end{array}$ & $\begin{array}{c}\text { Positive } \\
\text { cases } \\
\text { number }\end{array}$ & $\begin{array}{c}\text { All of studied } \\
\text { cases * }\end{array}$ & $\begin{array}{c}\text { Frequency } \\
\text { percent }\end{array}$ & $\begin{array}{c}\text { Positive } \\
\text { cases } \\
\text { number }\end{array}$ & $\begin{array}{c}\text { All of } \\
\text { studied } \\
\text { cases * }\end{array}$ & $\begin{array}{c}\text { Frequency } \\
\text { percent }\end{array}$ \\
\hline $\begin{array}{c}\text { Extermal root } \\
\text { resorption }\end{array}$ & 15 & 31 & 48.38 & 11 & 20 & 55 \\
\hline $\begin{array}{c}\text { Displacement of } \\
\text { adjacent teeth }\end{array}$ & 23 & 31 & 74.19 & 9 & 20 & 45 \\
\hline $\begin{array}{c}\text { Destruction of the } \\
\text { cortex }\end{array}$ & 5 & 8 & 62.5 & 7 & 7 & 100 \\
\hline $\begin{array}{c}\text { Displacement of the } \\
\text { nasal or sinus walls }\end{array}$ & 7 & 10 & 70 & 7 & 7 & 100 \\
\hline $\begin{array}{c}\text { Destruction of the } \\
\text { nasal or sinus walls }\end{array}$ & 0 & 4 & 0 & 2 & 4 & 50 \\
\hline $\begin{array}{c}\text { Displacement of the } \\
\text { mandibular canal }\end{array}$ & 8 & 21 & 38.09 & 9 & 12 & 75 \\
\hline Cortical expansion & 23 & 36 & 63.88 & 16 & 20 & 80 \\
\hline
\end{tabular}

*Based on the methods and material

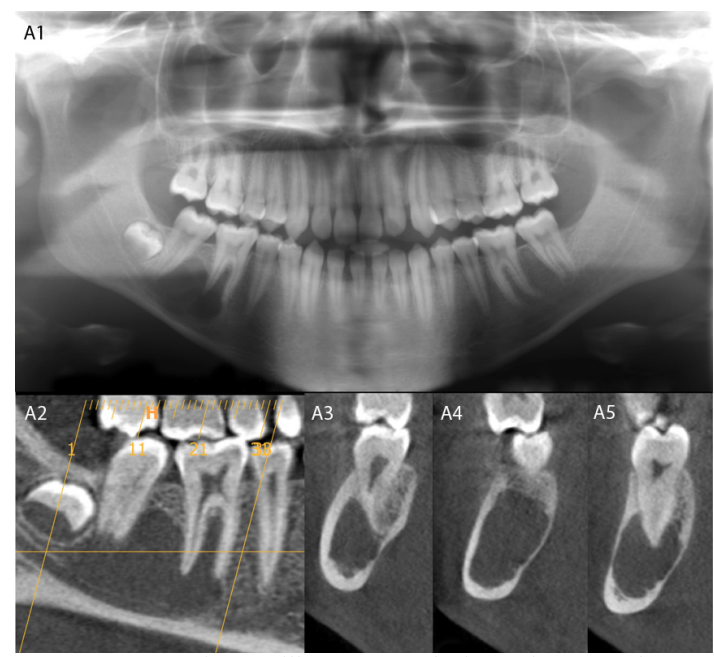

Fig.1. An OKC in maxilla. A:coronal view of CBCT shows two impacted teeth inside of lesion.B\&C: axial views in two different levels show buccal cortical expansion (C) and erosion (B).

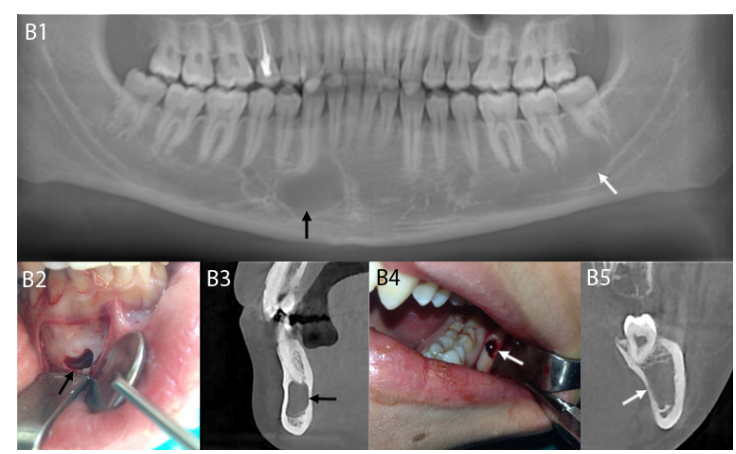

Fig.2. A dentigerous cyst in maxilla. A \& B: axial and sagittal scans of CBCT do not show any cortical expansion in maxillary sinus.

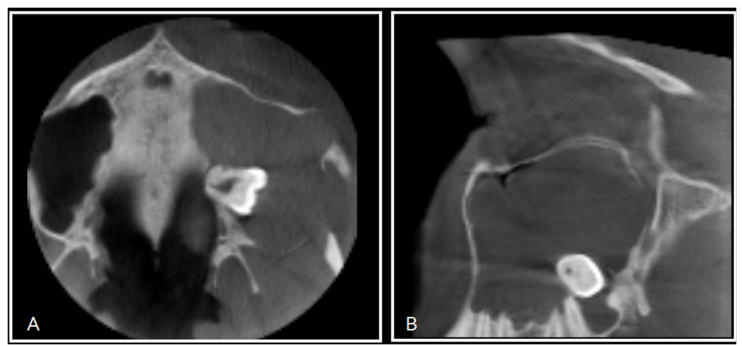

Fig.3. A large OKC in left maxilla. A\&B: axial and sagittal scans of CBCT: Note to the molar tooth position and erosion in the lateral wall of maxillary sinus.

\section{DISCUSSION}

Dentigerous cyst is the most common pathologic pericoronal radiolucency. It is the most prevalent odontogenic cyst after radicular cyst. Dentigerous cyst is associated with crown of impacted or developing teeth. Third mandibular molars, maxillary canines, mandibular premolars and third maxillary molars are the most common teeth affected with these lesions. These cysts vary in size from less than $2 \mathrm{~cm}$ to the extent that causes expanded jaws. Expanded jaw may cause deformity of the affected area. Although a cyst may slowly grow and cause thinning of cortical bone plates, it rarely destroys these plates. Dentigerous cysts cause resorption of adjacent teeth roots in 55\% of cases. ${ }^{7}$ Dentigerous cysts are frequently discovered whenradiographs are taken to investigate a failure of tootheruption, a missing tooth or malalignment. There is no painor discomfort associated with the cyst unless it becomessecondarily infected. ${ }^{7,8}$

Odontogenic keratocyst (OKC) accounts for 5 to $11 \%$ of cysts in jaws. This lesion is observed in mandible in $65 \%$ of cases and occur usually in the second and third decades of life. It is relatively more prevalent in men $(56.9 \%){ }^{6}$ Posterior body of mandible ( $90 \%$ occur posterior to the canines) and ramus (50\%) are the most common sites of OKC. The epicenter is located superior to the inferior alveolar nerve canal. This 
cyst sometimes has pericoronal position and is indistinguishable from dentigerous cyst. OKC has often a cortical border unless it is secondarily infected. The cyst may be round or oval or it may have a scalloped outline (a series of contiguous arcs). The most common internal structure is radiolucent. In some cases, the inner wall is curved and may give a multilacular appearance to the lesion. An important characteristic of the $\mathrm{OKC}$ is its propensity to grow along the internal aspect of the jaws, causing minimal expansion of the cortical plates. Relatively low expansion of these cysts causes delayed diagnosis of them, and sometimes these cysts reach a large size before being detected. OKC can cause tooth displacement and resorption but to a slightly lesser degree than dentigerous cysts. $^{7}$

Since there has been no comprehensive study to assess radiographic features of pericoronal radiolucencies and previous studies have been limited to a few cases reports, it seemed necessary to conduct a study for appropriate description of radiographic features of these lesions.

In this study, radiographic features of two common cases of pericoronal radiolucencies, including dentigerous cyst and OKC, were examined.

In the present study, out of 56 patients evaluated, there were 29 men (52\%) and 27 women $(48 \%)$. Although there has been no explanation to interpret these findings, comparison of results suggests that similar to many odontogenic cysts and tumors, the incidence of these lesions is slightly higher in men. ${ }^{9,10}$ However, in our study and Zhu in $2014^{11}$, OKC showed an equal prevalence among men and women, which was contrary to results of Gonzalez ${ }^{12}$ in which $51 \%$ of involved cases were males.

Both of dentigerous cysts and OKCs occurred most commonly in the second decade of life in this study. According to Tsukamoto et $a l$. in $2001^{13}$, odontogenic keratocyst occur with a peak in the second and third decades of life. In the study of Gonzalez in $2008^{12}$ and Kornafel in $2014^{9}$, stated that age peak of OKC occurs at the third decade of life. Moreover, according to the study of Imanimoghadam et al. ${ }^{14}$, there was a higher prevalence of dentigerous cyst in the second and $\mathrm{OKC}$ in the third decade of life. Perhaps this is related to odontogenesis process because it is the source of activity and subsequent differentiation of dental development.

Out of 36 dentigerous cysts studied, 26 $(72.2 \%)$ were in the mandible and $10(27.7 \%)$ were in the maxilla. Posterior mandible was the most common site of involvement for dentigerous cyst and OKC. According to Imanimoghadam et al. in $2007^{14}$, the most common sites of dentigerous cyst and $\mathrm{OKC}$ were anterior maxillary and posterior mandibular, respectively, which was contrary to our results with respect to dentigerous cyst. In the study of Gonzalez-Alva et al. ${ }^{12}$ in a Japanese population, similar results were obtained with ours. In this study, $70.5 \%$ of OKC were in mandible and $16.4 \%$ in the maxilla. In the study of Habibi et al. in $2007^{15}$ in which 83 cases of OKC were retrospectively reviewed over 10 years, $67.5 \%$ of lesions were in mandible and $32.5 \%$ were in maxilla. In the study of Sharifian et al. in $2011^{16}$, dentigerous cyst showed a higher tendency to maxilla. In our study, well-corticated margin was the most common external border in both dentigerous cyst and OKC. Results of other studies have demonstrated an obvious margin for pericoronal lesions, especially dentigerous cyst and odontogenic keratocyst. ${ }^{10,14}$ The most common border of cysts is well-corticated margin according to reference texts. Secondary infection at the site of lesion causes external border likely to disappear or thicken. ${ }^{6}$ In this study, four infected dentigerous cysts had sclerotic borders.

Imanimoghadam et al. $^{14}$ examined 41 panoramic radiography images including 26 
cases of dentigerous cyst and 15 odontogenic keratocyst, in which $30.77 \%$ of dentigerous cysts and $67 / 6 \%$ of OKCs caused root displacement of adjacent teeth. In addition, $34.62 \%$ of dentigerous cysts and $20 \%$ of OKCs caused root resorption of adjacent teeth. In our study, root resorption of adjacent teeth showed a higher prevalence in both lesions. In the study of Habibi et al. ${ }^{15}$, OKC-associated expansion was $45 \%$, which was $65 \%$ in the study of MacDonald $^{10}$, and was lower compared to our study $(80 \%)$. Higher prevalence of expansion associated with OKC in our study could be due to the fact that the majority of OKCs in our study occurred in ramus, which is usually associated with more expansion in this area. In our study, root resorption showed a higher prevalence in OKC compared to dentigerous cyst, which may be due to small size of the majority of dentigerous cysts in this study. This also justifies lower rate of expansion in this cyst compared to OKC, which was contrary to what was expected.

\section{CONCLUSIONS}

One of the most differential diagnoses to make is between a dentigerous cyst and OKC. When in a pericoronal position, an OKC may be indistinguishable from a dentigerous cyst. According to our results this lesion is likely to be an OKC if was seen destruction of buccal and lingual cortex and nasal and sinus walls.

Acknowledgments: This study was made possible by the generous support rendered by the Vice Chancellor for Research of Mashhad University of Medical Sciences, in the form of grant no 920335 for which the authors are very grateful.

\section{REFERENCES}

1. Kotrashetti VS, Kale AD, Bhalaerao SS, Hallikeremath SR. Histopathologic changes in soft tissue associated with radiographically normal impacted third molars. Indian J Dent Res. 2010; 21: 385-90.
2. Stathopoulos P, MezitisM, Kappatos C, Titsinides S, Stylogianni E. Cysts and Tumors associated with impacted third molars: Is prophylactic removal justified? J Oral MaxillofacSurg. 2011; 69:405-8.

3. Adelsperger J, Campbell JH, Coates DB, Summerlin DJ, Tomich CE. Early soft tissue pathosis associated with impacted third molars without pericoronal radiolucency. Oral Surg Oral Med Oral Pathol Oral Radiol Endod. 2000; 89:402-6.

4. Rakprasitkul S. Pathologic changes in pericoronal tissue of unerupted third molars. Quintessence Int. Sep 2001; 32:633-8

5. Villalba L, Stolbizer F, Blasce FC, Maurino N, Piloni MJ, Keszeler A. Pericoronal follicles of asymptomatic impacted teeth: a radiographic, histomorphologic, and immunohistochemical study. Int J Dent 2012; 23:121-124.

6. White SC, Pharoah MJ. Oral Radiology: Principles and Interpretation. $7^{\text {th }}$ edn. St. Louis, Mosby Co, 2014: 334-58.

7. Wood NK, Goaz PW. Differential diagnosis of oral and maxillofacial lesions. St Louis: Mosby Co, 1997: 251-79.

8. Devi P, Thimmarasa VB, Mehrotra V, Agarwal M.. Multiple Dentigerous Cysts: A Case Report and Review. J. Maxillofac. Oral Surg. 2015; 14:47-51.

9. Kornafel O, Jaźwiec P, Pakulski K. Giant Keratocystic Odontogenic Tumor of the Mandible - A Case Report. Pol J Radiol. 2014; 79:498-501.

10. MacDonald-Jankowski DS. Keratocystic odontogenic tumour: systematic review. Dentomaxillofacial Radiology. 2011; 40:1-23.

11. Zhu L, Yang J, Zheng JW. Radiological and clinical features of peripheral keratocystic odontogenic tumor. Int J Clin Exp Med. 2014; 7:300-306.

12. González-Alva $P$, Tanaka $A$, Oku $Y$, Yoshizawa D, Itoh S, Sakashita $\mathrm{H}$, et al. Keratocystic odontogenic tumor: a retrospective study of 183 cases. J Oral Sci. 2008; 50:205-12. 
13. Tsukamoto G, Sasaki A, Akiyama $T$, Ishikawa T, Kishimoto K, Nishiyama A, et al. A radiologic analysis of dentigerous cysts and odontogenic keratocysts associated with a mandibular third molar. Oral Surg Oral Med Oral Pathol Oral Radiol Endod. 2001; 91:743-7.

14. Imanimoghaddam $M$, MojeriKhazani $T$. The Evaluation of 41 Panoramic Radiographic Cases of Dentigerous Cysts and Odontogenic Keratocysts. JMDS. 2007; 31:1-6.

15. Habibi A, Saghravanian N, Habibi M, Mellati E, Habibi M. Keratocystic odontogenic tumor: a 10-year retrospective study of 83 cases in an Iranianpopulation. J Oral Sci. 2007; 49:229-35.

Conflict of interest: There are no conflicts of interest or financial ties to disclose.
16. Sharifian MJ, Khalili M. Odontogenic cysts: a retrospective study of 1227 cases in an Iranian population from 1987 to 2007 . J Oral Sci. 2011; 53:361-7.

\section{Correspondence author at}

Dr. Nasim Khaki,

School of Dentistry, Vakilabad Blvd, Mashhad, P.O. Box: 91735-984, Iran

Tel: +985118829501, +989124273208

Fax:+985117626058

E-mail: nasim.khaki.84@gmail.com 